\title{
Epipelic Diatom Communities in Pengilon Lake Dieng, Central Java
}

\author{
Tri Retnaningsih Soeprobowati ${ }^{1,2 *}$ Jumari $^{2}$, Riche Hariyati ${ }^{2}$, and Fini Wulandari ${ }^{2}$ \\ ${ }^{1}$ School of Postgraduate Studies, Diponegoro University, Semarang, Indonesia \\ ${ }^{2}$ Department Biology, Faculty Science and Mathematics Diponegoro University, Semarang, Indonesia
}

\begin{abstract}
Diatom communities in the lake have an advantage of environmental assessment and paleo reconstruction study, due to the ability of diatom preserved in the sediment. There are only limited studies about taxonomy, ecology, and diversity of diatom flora in tropical areas, especially Indonesia. The main objective of the research is to describe the structure of benthic diatom communities in Pengilon Lake, together with physical chemical variables. Sediment samples were collected at an altitude of more than 2,000 msal habitats with $\mathrm{pH}$ around 5.40-6.86. A total of 83 diatom species identified as belonging to 16 families. The diversity index ranges from about 2.25 to 3.01 indicated the ecosystem that naturally stable with none diatom dominant. The most abundant genera were Eunotia with high diversity around 14 taxa. The composition of Eunotia assemblages was different among habitat and season variation. Eunotia has a wide tolerance of $\mathrm{pH}$ because of its ability to survive in an area with an acidic environment and circumneutral water. The most dominance diatom species in Pengilon Lake were Eunotia paludosa (Grunow) 39.2\%, Nitzschia frustulum (Kutzing) 28.1\%, Pinnularia viridis (Krammer \& Lange-Bertalot) and Pinnularia divergentissima (Grunow) 24.6\%.
\end{abstract}

Keywords: epipelic; diatom; community; Pengilon; Dieng; Eunotia.

\section{Introduction}

Indonesia territory located in the equator area that receives a lot of sunlight concentration throughout the year, the presence of sunlight is used up to evaporating water from waterbodies. Tropical aquatic has constant temperature during the year, the temperature is considered an important role for determining the structural and temporal changes in diversity organism. Composition changes for diatom assemblages are affected by the complex interaction of physical, chemical and biological factors. Interactions among the factors cause a response to diatom composition. The diversity and species composition of diatom has studied by diatomist for a century, but the pattern of diatom composition in the tropical area has also been unclear also the research about diatom communities in the tropical mountain area is still limited [1-3].

Dieng is the widest plateau in Java and located in Wonosobo and Banjarnegara Indonesia with the altitude around 2000 - 2500 masl with coordinate E $7^{\circ} 04^{\prime}-7^{\circ} 13^{\prime}$ and S $109^{\circ} 32^{\prime}-109^{\circ} 56^{\prime}$, annual rainfall rate $2270-4835$ $\mathrm{mm} /$ year. Dieng vulcanic territory was formed by primordial mountain crater from three volcanic activities since the caldera era 10,000 years ago that obtained 20 geological craters with active hydrothermal activity such as lava domes, cinder cones, hot spring, acid crater lake.

There is various aquatic ecosystem around Dieng plateau one of them is Telaga Pengilon, the lake was formed by volcanic activity $[4,5]$. Pengilon Lake is a shallow permanent lake located in Dieng plateau, Wonosobo Indonesia. Pengilon Lake well known as a mirror lake for local people determines that the lake has clear water. Pengilon Lake has a function for irrigation for agricultural products such as potatoes, cabbage, carica, and carrot [6].

Pengilon Lake is well known for its tourist attraction and potential as a water source for agricultural irrigation. Next to Pengilon Lake, there is Warna Lake, these habitats are characterized by different ecological conditions, which is specialized in $\mathrm{pH}$ fluctuation. Warna Lake tends to acidic with $\mathrm{pH}$ around 2.2-5.35 and Pengilon Lake has a $\mathrm{pH}$ around 2.52-7.9 which is more to circumneutral water. Pengilon Lake is determined as a conservation area based on Rule of the Minister of Agriculture No. $740 / \mathrm{Kpts} / \mathrm{Um} / 11 / 197830$ November 1978 that stated the total conservation area around Pengilon lake about 39.6 ha $[7,8]$. The different ecological conditions affected the diatom assemblages around the lake.

Diatom well known as Bacillariophytes and naturally found in all aquatic environments, diatom has a specialization cell wall called frustule made of silicacoated with organic material. Diatom playing a fundamental part in lentic ecosystem for primary production, the food source for various aquatic organisms. Benthic diatom is the major autotropic group in the

* Corresponding author: trsoeprobowati@live.undip.ac.id 
sediment that contributes $50 \%$ carbon fixation in the ecosystem and sensitive to water quality changes $[9,10]$.

Bio indicator research has fast-growing in order to monitor the changes in water quality. Diatom communities have been used frequently as an environmental assessment in paleolimnological study causes their ability to respond to environmental changes $[11,12]$. The implementation of benthic diatom for biomonitoring aquatic ecosystems has been widely used. Diatom is useful as an indicator to determine the water condition, the function of diatom as an indicator has been used since the $18^{\text {th }}$ century [13].

\section{Methods}

The study was carried out in four different sites located in Pengilon Lake, Dieng. Sediment samples were collected on April 2019, the sample sites are located in location near Warna Lake (TP1) around the channel of Pengilon lake, TP2 represents the area near with agriculture, TP3 is located in the forest around lake that dominated with grass and TP4 is area with highest sediment deposition (Fig 1).

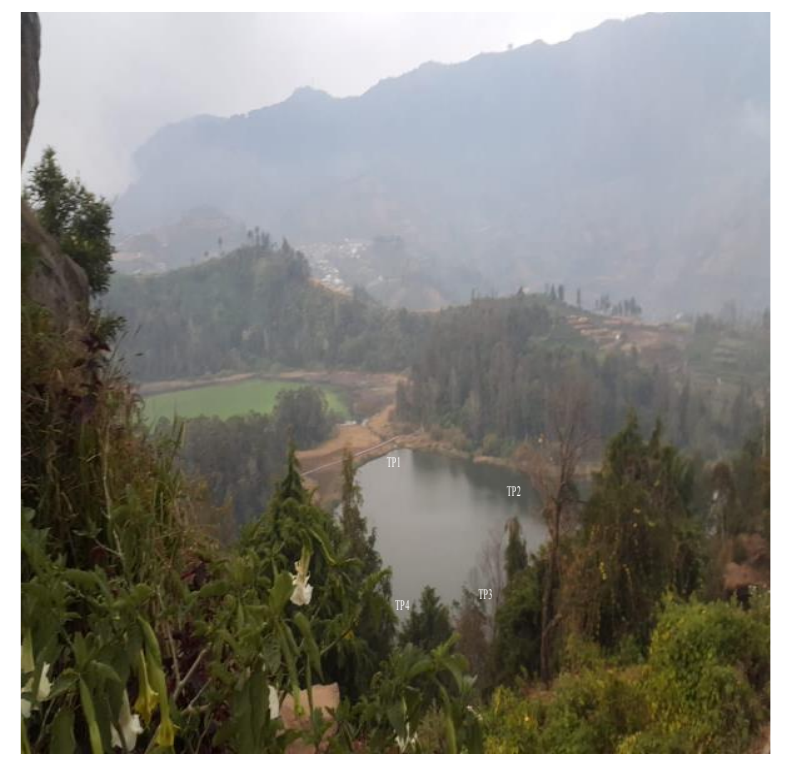

Fig 1. Research sites in Pengilon Lake Dieng, Central Java

Diatom analysis was divided into three different steps first digestion, preparation, and identification. The first, samples were freeze-dried and approximately 1 gram of each sample was measured and used for extraction of diatom, Samples were digested using acid $(50 \mathrm{ml}$ Hydrochloride acid 10\%) heated approximately for 2 hours. Excess acid was removed using distilled water. The sample processes were repeated using different acid (50 $\mathrm{ml}$ hydrogen peroxide $10 \%$ ) in order to remove all material organic and carbonate. Microscopic slides were mounted using Naphrax, the last process was the identification process using [14-18], algabase.org and westerndiatom.colorado.edu.

\section{Result}

Pengilon Lake is deeper than Warna Lake which is connected by the natural corridor. That is why during the wet season the water is flowing from Pengilon Lake to Warna Lake, as the outlet is on Warna Lake. However, during the dry season, the water flows from Warna to Pengilon Lake due to 80 water pumps in the Pengilon Lake. As a result, Warna Lake dried and the lowest tide reduced up 3 meters during the dry season in April 2019 (Fig. 2-4).

Local people use water from Pengilon Lake to irrigate the crops. On average, the water is pumped reduced 266.67 L/second. By the Law, people able to use water from the lakes, but many numbers of pumps, will induce the water crisis in the future (Fig 5, Fig 6).

On the other hand, a high sedimentation rate due to land exploitation runs out to the lake (Fig 7, Fig 8). It was predicted that that within 10 years the lake will be dried (Some of the lakes in Dieng had dried out, such as Swiwi, Siterus, and Balekambang Lakes. The water volume of other lakes such as Warna, Pengilon, Merdada, Cebong, Dringo tends to reduce, particularly in the dry season.

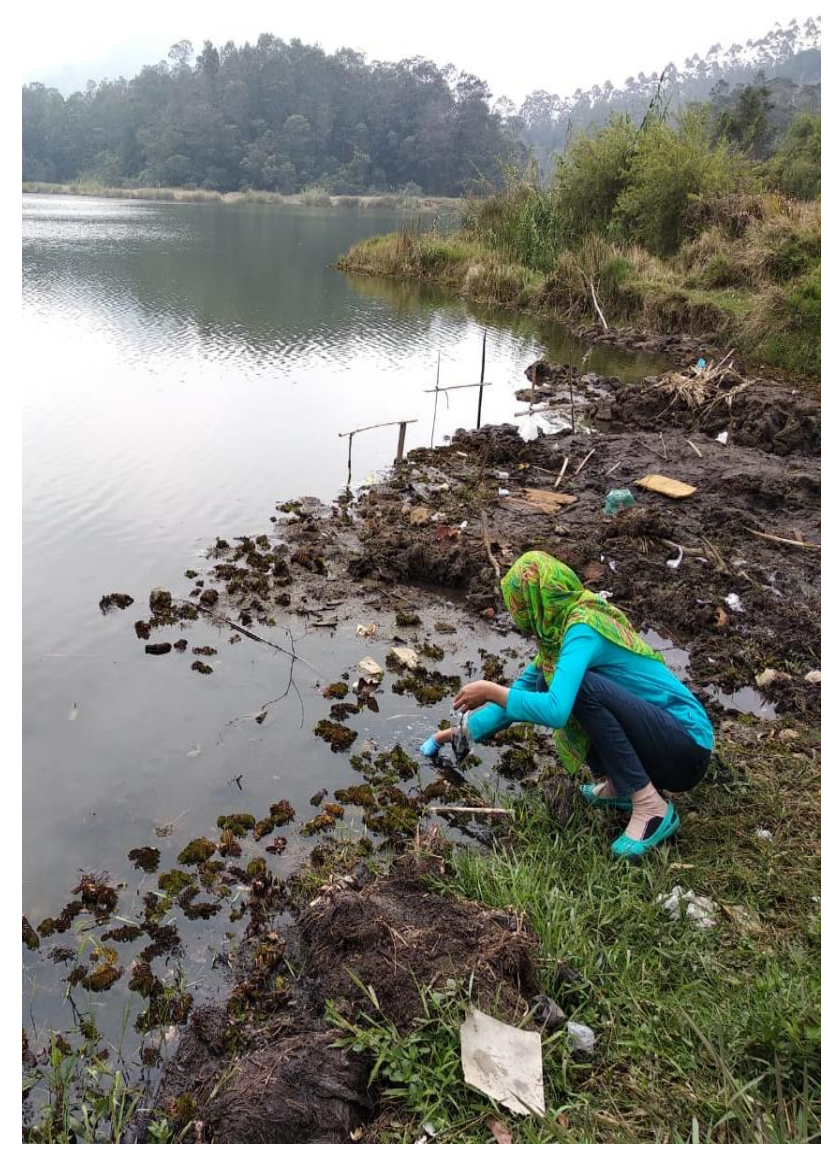

Fig 2. Pengilon Lake is dried, April 2019 


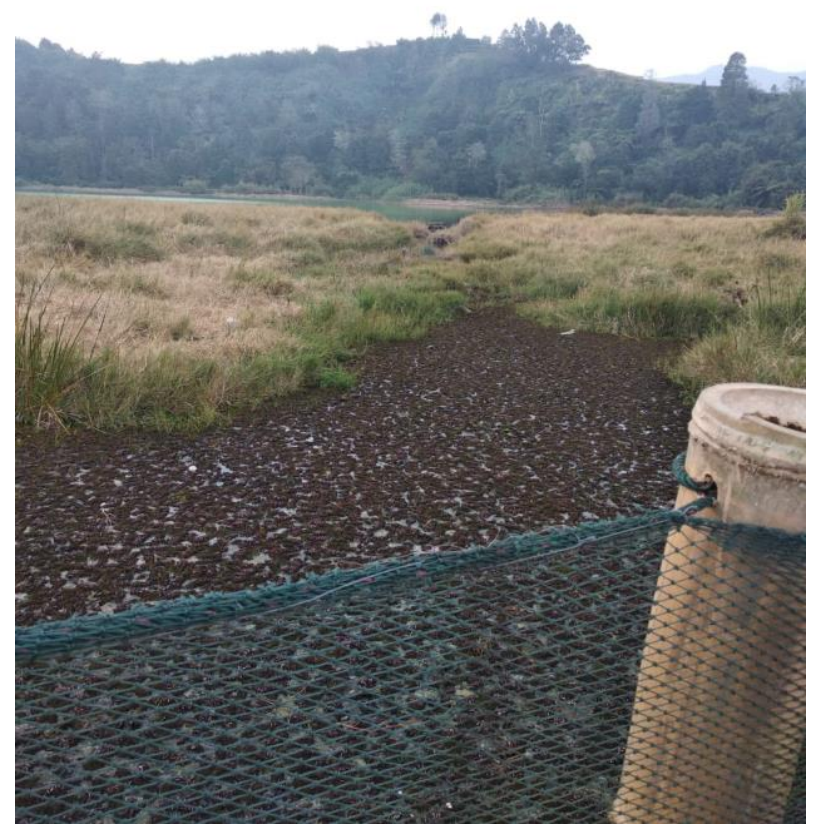

Fig 3. Pengilon and Warna Lakes are connected. The corridor is dried in dry seaso

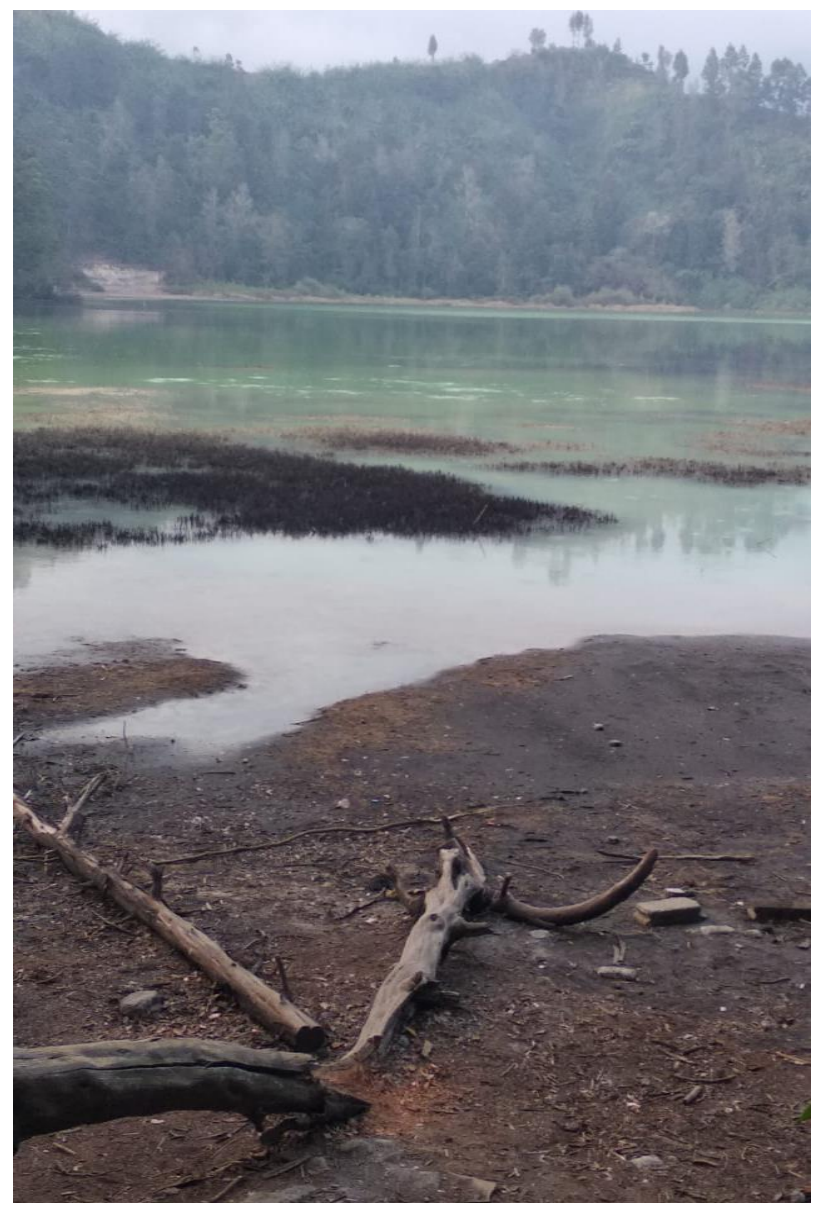

Fig 4. Warna Lake is dried, the lowest tidal reduced up to 3 meters during dry season, April 2019

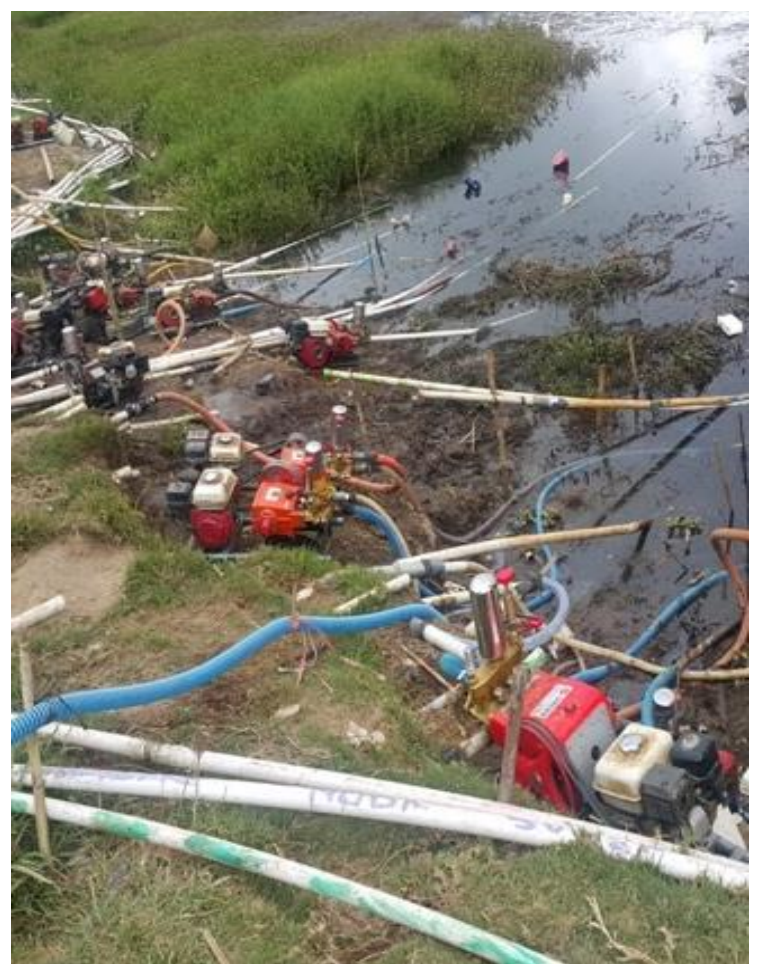

Fig 5. Pumping water from Pengilon Lake for crop plantation, piped up to the hill

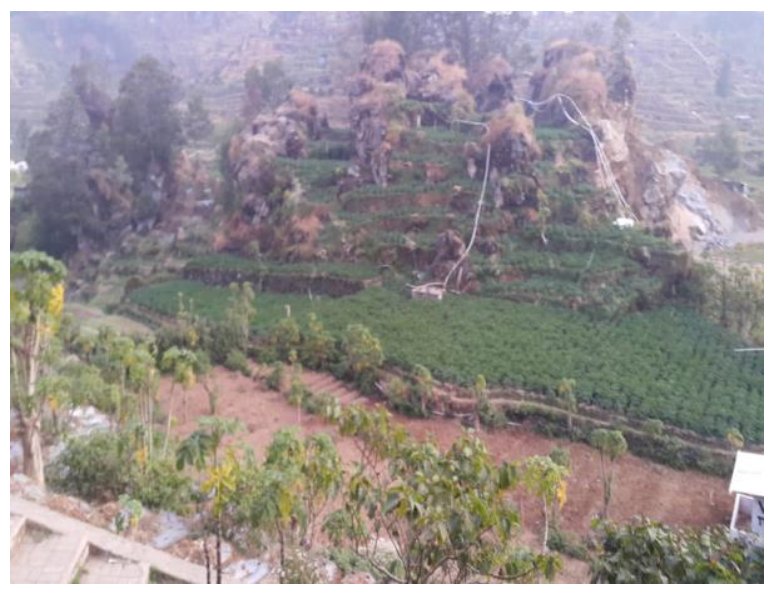

Fig 6. Piped of water for crop plantation up to the hill

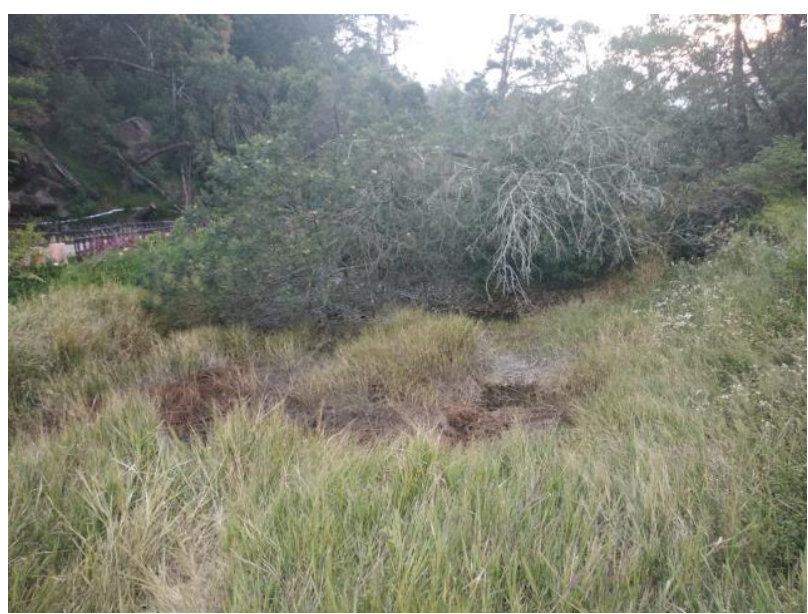

Fig 7. Piped of water for crop plantation up to the hill 


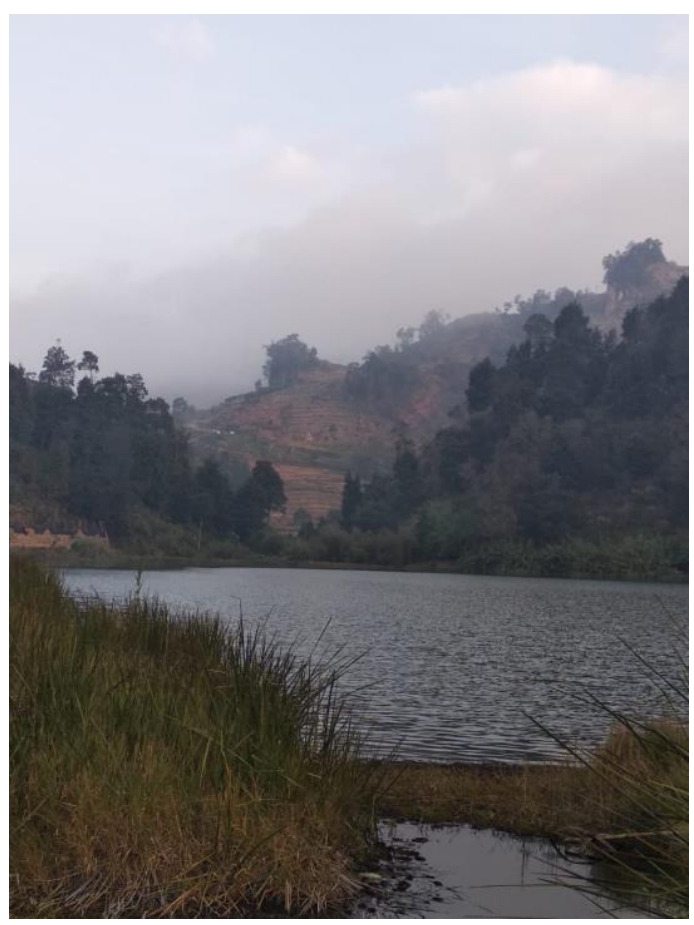

Fig 8. The land use changes into crops plantation, up to the slope hill

Water volume changes in Pengilon Lake influence epipelic diatom communities. Epipelic is diatom that found at lake sediment. A total of 83 species diatoms were identified from sediment samples of Pengilon Lake and belonging to 25 genera, the abundant species were Eunotia paludosa (Grunow) with abundance $39.2 \%$, Nitzschia frustulum (Kutzing) 28.1\%, Pinnularia viridis (Krammer \& Lange-Bertalot) and Pinnularia divergentissima (Grunow) $24.6 \%$ (Fig. 9). The most common genera were Eunotia (16 genus). Over $50 \%$ of the total diatom counted were from genus Eunotia. Frustulia crasinervia (Breb.) mostly found in the area where water moves through the channel delivered to Warna Lake, indicated that the areas have low mineral content and acidic water.

Frustulia crasinervia (Breb.) consider as cosmopolitan species that commonly found in mesotrophic- eutrophic water bodies [15, 17]. Eunotia paludosa (Grunow) was the common species found in the area nearby agriculture and irrigation source. Eunotia paludosa (Grunow) is a benthic diatom that commonly found in the area where the water moves flow such as river and indicated dystrophic condition. Eunotia paludosa (Grunow) could live in the water with a high content of sulfate and acidic water with a low $\mathrm{pH}$ about 4$5[14,18]$.

Nitzschia has wide distribution and an important role in the environment. Nitzschia frustulum commonly found in various habitats such as fresh, coastal and marine waters. Some Nitzschia species are indicators of heavy metal contamination and eutrophic conditions [19]. Pinnularia divergentissima was abundant species and commonly found in TP 4.

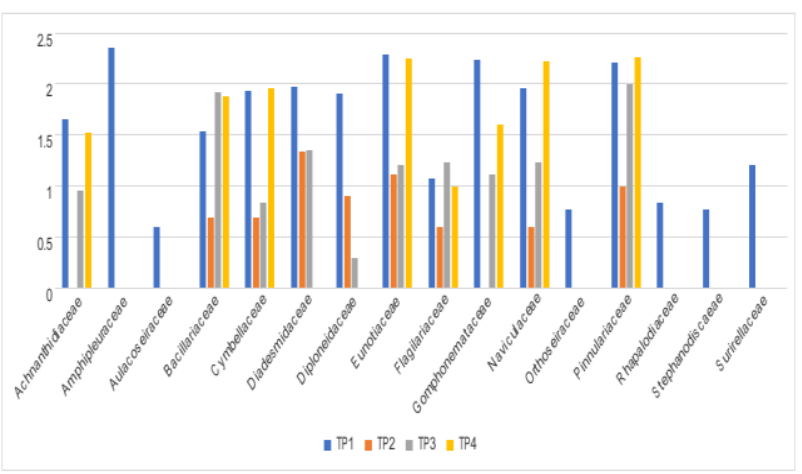

Fig 9. Diatom abondance in Pengilon Lake Dieng, Central Java

Pinnularia divergentissima included benthic diatom species that are found in freshwater with epiphytic and epilithic conditions [20].

There were several Eunotia species that abundance in Warna Lake and Pengilon Lake such as Eunotia bilunaris var. linearis, Eunotia bilunaris var. mucophila and Eunotia paludosa. Many Eunotia species are found due to Eunotia having a wide $\mathrm{pH}$ range and has tolerance and resistance to areas with fluctuation of $\mathrm{pH}$ and basic $\mathrm{pH}$ fluctuations [8]. This is supported by [13] that most of the records found and distribution of the Eunotia are from studies on aquatic habitats in the mountains, as well as lakes in the highlands.

\section{Conclusion}

Based on this study, there were 83 epipelic diatoms were found in Pengilon Lake, which belongs to 25 genera. The genera that found with many species is Eunotia, and the most abundant species was Eunotia paludosa (Grunow), Nitzschia frustulum (Kutzing), Pinnularia viridis (Krammer \& Lange-Bertalot) and Pinnularia divergentissima (Grunow), respectively.

\section{Acknowledgments}

We thank to Directorate Research and Community Service, Directorate General Research Strengthen and Development, The Ministry of Higher Education and Research and Technology with the research grant number: 101-120/UN7.P4.3/PP/2019. Special thanks for Kenanga Sari for helping on the analysis.

\section{References}

1. J. Padisak, E. Hajnal, L. Naselli-Flores, M.T. Dokulil, P. Noges, T. Zohary, Hydrobiol 639, 205220 (2010)

2. N.L. Lopez, C.A.R. Randon, A. Zapata, J. Jimenez, W. Villamil, G. Arenas, C. Rincon, T. Sanchez. Limnetica 31, 305-322 (2012)

3. S. Hadisusanto, Faculty of Biology, UGM (2015)

4. M.J. Van Bergen, T. Sriwana, A. Bernard, S. Sumarti, K. Sitorus, IAVCEI (2000)

5. A.F. Pradana, F.H. Sara, W. Wahdaningrum. Intl J. Env Sci Dev 11(6), 861-867 (2015) 
6. Sudarmadji, S. Heri, S. Lestari J. Teknosains 5(1), 18 (2015)

7. T.R. Soeprobowati, S.W.A. Suedy, Hadiyanto. IOP Earth Env Sci 55, 1-6 (2016)

8. K. Sari, J.W. Hidayat, T.R. Soeprobowati, Intl Res J Env Sci 7(11), 1-6 (2018)

9. S.B. Faustino, C.E. de Mattos Bicudo, L. Fontana, E.C.R. Bartozek, D. de Campos Bicudo. Biota Neotropica 16(2), 1-23 (2016)

10. J. Bohorquez, T.J. McGenity, S. Paspaspyrou, E.G. Robledo, A. Corzo, G,J,C. Underwood, Frontier microbiol 8, 245 (2017)

11. T. Bere, T. Mangadze, T. Trop ecol 55(2), 271-281 (2014)

12. T.R. Soeprobowati, S.W.A. Suedy, Hadiyanto, A.A. Lubis, P. Gell, Env Tech Innov 10(1), 314-323 (2018)

13. A. Pavlov, Z. Levkov. Phytotaxa 86(1), 1-117 (2013)

14. E. Alles, M. Nörpel-Schempp, H. Lange- Bertalot, Nova Hedwigia 53, 171- 213 (1991)

15. H. Lange-Bertalot, D. Metzeltin, Koeltz Sci Books 2, 390 (1996)

16. P.A. Gell, A. Sonneman, M.A. Reid, M.A. Illman, A.J. Sincock. (1999)

17. H. Lange-Bertalot, H. Diatoms of Euro 2, 1-526 (2001)

18. J.C. Taylor, W.R. Harding, C.G.M Archibald (2007)

19. G. Martin, J. Toja, S.E. Sala, R. Fernandez, I. Reyes, M.A. Casco, 170, 519-534 (2010)

20. M.D. Guiry, G.M. Guiry. AlgaeBase (2019) 